Journal home page: http://chimie-biologie.ubm.ro/carpathian_journal/index.html

\title{
COMPARISON OF CHEMICAL COMPOSITION AND PHYSICOCHEMICAL PROPERTIES OF PEKIN DUCK AND CHERRY VALLEY DUCK EGGS
}

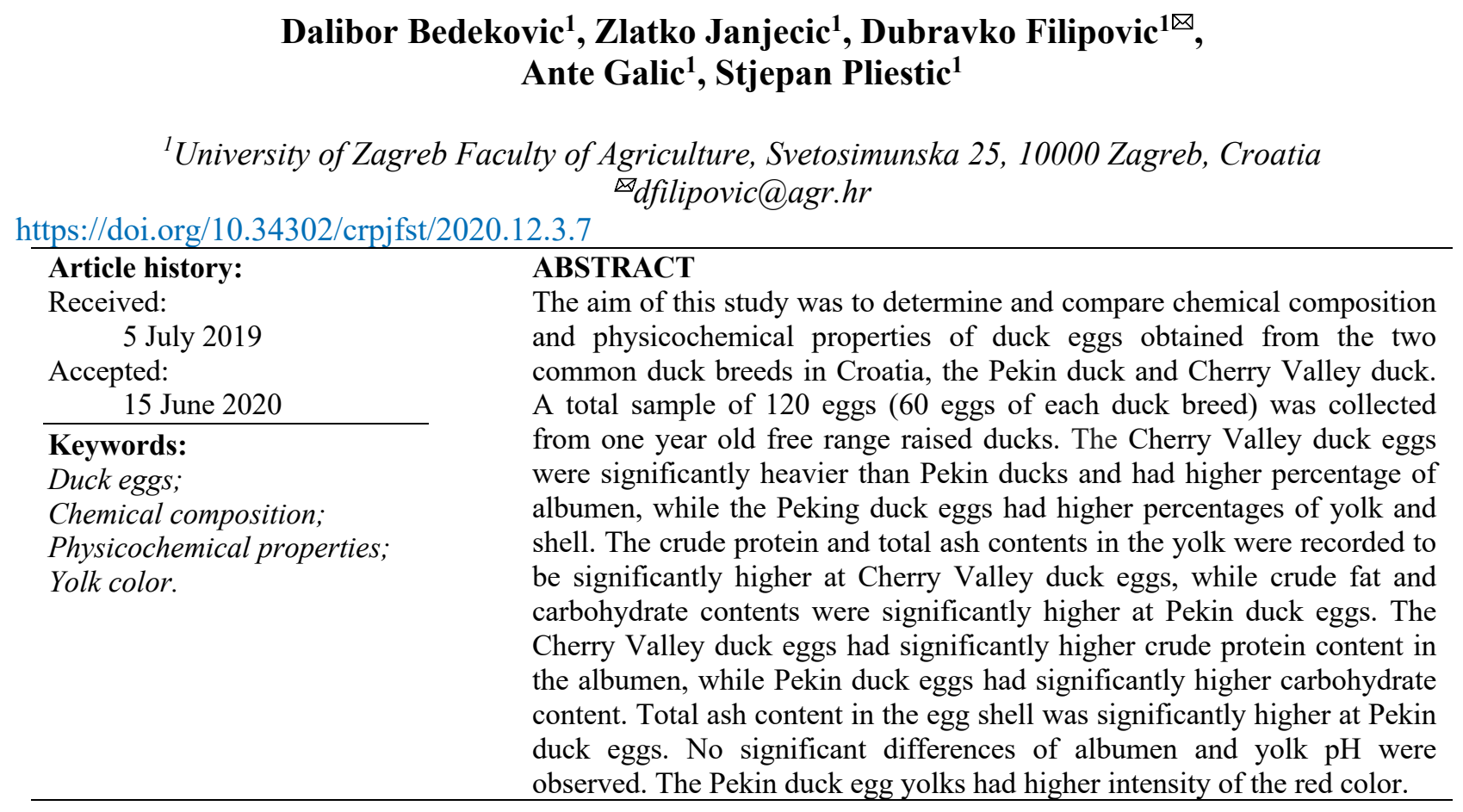

\section{Introduction}

Eggs are sources of protein, fats and micronutrients that play an important role in basic nutrition (Miranda et al., 2015). Egg consumption differs widely among countries, with per capita consumption being high among the developed countries (Ayim-Akonor and Akonor, 2014). Hen and duck eggs are the most commonly eaten eggs, and are highly nutritious (Kaewmanee et al., 2009). The duck eggs has become increasingly more important in the world because of its nutrition and less capital input is required to produce it. In several countries of the Far East duck eggs are produced and consumed in large quantities by the local population for many years, but duck eggs are usually not consumed in the countries in America and Europe in the second half of the 20th century, mostly due to the potential Salmonella risk (Huang and Lin, 2011).
However, in the first part of the 21st century, there has been an increase in the use of duck eggs. The study of Owen et al. (2016) has shown that Salmonella spp. was detected only in two of 145 samples of ducks eggs, similar to that found in hen eggs.

Ducks produce larger eggs with more nutrients and contain relatively less water and higher percentage of proteins and fats in the yolk, albumen and total contents of egg as compared to hen eggs (Etuk et al., 2012). Duck eggs also have a relative higher percentage of egg yolk compared with other avian eggs. This favors duck eggs when the products utilize the egg yolk instead of whole egg (Huang and Lin, 2011). Duck eggs provide plenty of complete, high-quality protein (which includes all amino acids essential for humans) and supply many substances with biological functions beyond basic nutrition (Lopez-Fandino et al., 2007). 
Duck breeding has also received immense attention due to its higher profitability compared to other poultry species, mainly due to higher feed conversion ratios (El-Soukkary et al., 2005). Market demand is progressively focused on high quality products (organic or others sustainable production under quality control) which requires free range conditions. One of the reasons is that intensive production conveys a negative picture of the welfare of the animals, and the products are generally considered low quality (Huang et al., 2012). According to that demand, an increasing number of family farms in Croatia starting with duck raising in the backyard under free range conditions where the number varies from a few dozen to a few hundred ducks.

Knowledge of the egg chemical composition and the physicochemical properties of its individual components can increase the potential applications in the food industry and can also enhance our understanding of various biological processes (Raikos et al., 2006). This knowledge should be also useful for interpreting the changes that occur during egg storage and during pasteurizing, drying and freezing (Powrie and Nakai, 1999).

A few studies were found in the literature about chemical composition and the physicochemical properties of Pekin duck eggs, but there is scarity of literature about chemical composition and the physicochemical properties of Cherry Valley duck eggs. The aim of this study was to determine and compare chemical composition and physicochemical properties of duck eggs obtained from the two most common duck breeds in Croatia, the Pekin duck and Cherry Valley duck.

\section{Materials and methods}

\subsection{Materials}

\subsubsection{Samples}

Duck eggs used in this study were collected from two family farms located within a circle of $60 \mathrm{~km}$ of the Zagreb, capitol of Croatia. On the first farm located near Krizevci (latitude $46^{\circ} 01^{\prime} \mathrm{N}$, longitude $16^{\circ} 32^{\prime}$ E) Pekin ducks were breeding, and on the second farm located near Ivanic Grad (latitude $45^{\circ} 43^{\prime} \mathrm{N}$, longitude $16^{\circ} 23^{\prime}$ E) Cherry Valley ducks were breeding. Both farms have annual production of about hundred ducks. On both farms ducks are free range raised and fed with combined forage based on cereals and with kitchen waste. Ducks spend only the night in a closed object, while during the day they are on the fenced area with allowed access to open water. According to size and housing system those farms are similar to most duck farms from that part of Croatia. Eggs were randomly collected during May 2018 from one year old female ducks. A total sample of 120 eggs was evaluated, consisting of 60 eggs collected from each duck breed.

\subsection{Methods}

\subsubsection{Egg weight and composition}

To evaluate the total egg weight, eggs were separately weighed on a precision electronic balance reading to $0.01 \mathrm{~g}$. Before weighing the yolk, the chalazae were carefully removed from the yolk and the yolks were separated from the albumen. All yolks were also rolled on a paper towel to remove adhering albumen. The shells were carefully washed and dried for $48 \mathrm{~h}$ in a drying oven at $21^{\circ} \mathrm{C}$ and then weighed. Albumen weight was determined by subtracting yolk weight and shell weight from the original egg weight. Using the individual weight of each egg and its components, albumen percentage (albumen weight/egg weight x 100), yolk percentage (yolk weight/egg weight $x$ 100) and shell percentage (shell weight/egg weight $\mathrm{x}$ 100) were calculated.

\subsubsection{Egg chemical composition}

The basic chemical composition of egg albumen, yolk and shell was analyzed by the standard methods of AOAC (1980). The dry matter content was determined by drying a sample at $100^{\circ} \mathrm{C}$ until constant weight according to AOAC method 925.30. The crude protein content resulted from total nitrogen content assessment via the Kjeldahl method, according to AOAC method 925.31. The total nitrogen content was multiplied by 6.25 , which generated the crude protein content. Total lipids 
as crude fat content was determined by AOAC method 925.32. The total ash content was assessed via incinerating at $550{ }^{\circ} \mathrm{C}$ in accordance with AOAC method 900.02. The carbohydrate content was calculated as the difference between $100 \%$ and the sum of the percentages of water, crude protein, crude fat, total ash and crude fibre. The egg shell calcium content was determined by complexometric method and phosphorus content was determined by spectrometric method.

\subsubsection{Egg physicochemical properties}

The $\mathrm{pH}$ of egg yolk and albumen were measured by using a digital $\mathrm{pH}$ meter Mettler Toledo SevenMulti (Mettler-Toledo GmbH, Greifensee, Switzerland). For measurement of yolk color according to CIE (1986) $\mathrm{L}^{*} \mathrm{a}^{*} \mathrm{~b}^{*}$ color system a Minolta Chroma Meter CR-310 (Minolta Camera Co. Ltd, Osaka, Japan) was used. The $\mathrm{L}^{*}$ value indicates the lightness, representing dark to light $(0-100)$. The $\mathrm{a}^{*}$ (redness) value indicates the degree of the redgreen color, with a higher positive $a^{*}$ value indicating more red color. The $b^{*}$ (yellowness) value indicates the degree of the yellow-blue color, with a higher positive $b^{*}$ value indicating more yellow color. Subjective yolk color was determined using the Roche Yolk Color Fan (DSM Nutritional Products, Kaiseraugst, Switzerland) by one person.

\subsubsection{Statistical analysis}

Statistical data analysis was done with the SAS software (SAS Institute, 2004). The results were expressed as mean value \pm standard deviation (SD) of 60 measurements for egg chemical and physicochemical properties for each duck breed. The significance of differences between the values of observed parameters was assessed by analysis of variance (ANOVA). The Fisher's least significant difference (LSD) test was used to compare the means and differences were considered as significant at the level of probability $\mathrm{P}<0.05$.

\section{Results and discussions}

\subsection{Egg weight and composition}

The total weight and composition of Pekin duck and Cherry Valley duck eggs are presented in Table 1. The total weight of the Cherry Valley duck eggs and the weight of egg components (albumen, yolk and shell) was significantly higher at Cherry Valley duck eggs $(\mathrm{P}<0.05)$. There is deficit of technical information and data in the scientific literature about physical and chemical characteristics of Cherry Valley duck eggs, so results obtained in this study were compared with the characteristics of Pekin duck eggs published by other authors. The average weight of Pekin duck eggs observed in this study (71.91 g) was higher than weight of Pekin duck egg reported by Balkan and Biricik (2008) with $69.51 \mathrm{~g}$, but other authors reported higher values like 77.57 $\mathrm{g}$ (Kralik et al., 2015), $80.7 \mathrm{~g}$ (Kokoszynski et al., 2007), 82.1-83.8 g (Onbasilar et al., 2007), 82.8-86.7 g (Okruszek et al., 2008), 91-45$95.56 \mathrm{~g}$ (Biesiada-Drzazga et al., 2014) $91.89 \mathrm{~g}$ (Al-Obaidi and Al-Shadeedi, 2016) and $97.31 \mathrm{~g}$ (Yuan et al., 2013). Statistical analysis revealed that significant differences were also appeared in the components percentage. The albumen percentage was significantly higher $(\mathrm{P}<0.05)$ at Cherry Valley duck eggs, while yolk and shell percentages were significantly higher $(\mathrm{P}<0.05)$ at Pekin duck eggs. The albumen percentage of Pekin duck eggs observed in this study $(52.19 \%)$ was close to albumen percentage of Pekin duck eggs reported by Ipek and Sozcu (2017) in range 52.7-54.5\% and in range 52.21$53.44 \%$ reported by Biesiada-Drzazga et al. (2014), but lower than albumen percentage of Pekin duck eggs of $53.51 \%$ reported by Balkan and Biricik (2008) and 55.35\% reported by AlObaidi and Al-Shadeedi (2016). The yolk percentage of Pekin duck eggs observed in this study $(35.16 \%)$ was higher than yolk percentage of Pekin duck eggs of 34.06\% reported by Balkan and Biricik (2008) and $32.26 \%$ reported by Al-Obaidi and Al-Shadeedi (2016), but lower than yolk percentage of Pekin duck eggs in range of $39.2-40.8 \%$ reported by Okruszek et al. (2008). According to Ipek and 
Sozcu (2017), the quantity of yolk and albumen in duck eggs is altered depending on changes in egg weight. The shell percentage of Pekin duck eggs observed in this study $(12.65 \%)$ was close to shell percentage of Pekin duck eggs of $12.39 \%$ reported by Al-Obaidi and Al-Shadeedi (2016), but higher than shell percentage of
Pekin duck eggs in range $8.9-9.9 \%$ reported by Ipek andnd Sozcu (2017) and 8.91-9.12\% reported by Okruszek et al. (2008). The considerably higher shell percentage of Pekin duck eggs in range $13.55-14.61 \%$ was reported by Biesiada-Drzazga et al. (2014).

Table 1. Comparison of total weight and composition of Pekin duck and Cherry Valley duck eggs

\begin{tabular}{|l|c|c|}
\hline \multirow{2}{*}{ Parameter } & \multicolumn{2}{|c|}{ Sample } \\
\cline { 2 - 3 } & Pekin duck & Cherry Valley duck \\
\hline Total weight $(\mathrm{g})$ & $71.91 \pm 5.14^{\mathrm{a}}$ & $94.23 \pm 4.89^{\mathrm{b}}$ \\
\hline Albumen weight $(\mathrm{g})$ & $37.58 \pm 3.87^{\mathrm{a}}$ & $51.72 \pm 4.06^{\mathrm{b}}$ \\
\hline Albumen percentage (\%) & $52.19 \pm 3.08^{\mathrm{a}}$ & $54.85 \pm 2.29^{\mathrm{b}}$ \\
\hline Yolk weight (g) & $25.26 \pm 2.67^{\mathrm{a}}$ & $31.21 \pm 1.93^{\mathrm{b}}$ \\
\hline Yolk percentage (\%) & $35.16 \pm 3.32^{\mathrm{a}}$ & $33.17 \pm 2.26^{\mathrm{b}}$ \\
\hline Shell weight (g) & $9.07 \pm 0.54^{\mathrm{a}}$ & $11.30 \pm 0.81^{\mathrm{b}}$ \\
\hline Shell percentage (\%) & $12.65 \pm 0.73^{\mathrm{a}}$ & $11.98 \pm 0.35^{\mathrm{b}}$ \\
\hline
\end{tabular}

Values are averages of 60 samples \pm standard deviation

Values in the same row followed by different letters are significantly different $(\mathrm{P}<0.05)$

\subsection{Egg chemical composition}

Analysis of chemical composition of the egg yolk showed significant differences between Pekin duck and Cherry Valley duck eggs (Table 2). The crude protein and total ash contents in yolk were recorded to be significantly higher $(\mathrm{P}<0.05)$ at Cherry Valley duck eggs, while crude fat and carbohydrate contents were significantly higher $(\mathrm{P}<0.05)$ at Pekin duck eggs. No significant differences were observed in dry matter percentage values between Pekin duck and Cherry Valley duck eggs.

Table 2. Comparison of yolk chemical composition of Pekin duck and Cherry Valley duck eggs

\begin{tabular}{|c|c|c|}
\hline \multirow{2}{*}{ Parameter } & \multicolumn{2}{|c|}{ Sample } \\
\cline { 2 - 3 } & Pekin duck & Cherry Valley duck \\
\hline Dry matter, \% & $55.40 \pm 0.89^{\mathrm{a}}$ & $55.33 \pm 0.37^{\mathrm{a}}$ \\
\hline Crude protein, \% & $15.76 \pm 0.35^{\mathrm{a}}$ & $17.29 \pm 0.52^{\mathrm{b}}$ \\
\hline Crude fat, \% & $35.90 \pm 0.75^{\mathrm{a}}$ & $34.46 \pm 0.70^{\mathrm{b}}$ \\
\hline Total ash, \% & $1.92 \pm 0.15^{\mathrm{a}}$ & $2.71 \pm 0.22^{\mathrm{b}}$ \\
\hline Carbohydrate, \% & $1.82 \pm 0.28^{\mathrm{a}}$ & $0.87 \pm 0.25^{\mathrm{b}}$ \\
\hline
\end{tabular}

Values are averages of 60 samples \pm standard deviation Values in the same row followed by different letters are significantly different $(\mathrm{P}<0.05)$

The yolk dry matter percentages of both Pekin duck and Cherry Valley duck eggs observed in this study $(55.40 \%$ and $55.33 \%$, respectively) were close to yolk dry matter percentage of Pekin duck eggs in range 54.8$55.5 \%$ reported by Ipek and Sozcu (2017),
$55.14 \%$ reported by Balkan and Biricik (2008) and $55.8 \%$ reported by Sekiguchi et al. (1979), higher than dry matter percentage of Pekin duck eggs in range $50.4-51.0 \%$ reported by Okruszek et al. (2008) and lower than dry matter percentage of Pekin duck eggs in range 
$56.27-57.68 \%$ reported by Onbasilar et al. (2011). Egg polyfunctionality in food systems is correlated, to a high extent, with its chemical composition and more specifically with its

According to Kaewmanee et al. (2009), duck egg yolk was rich in protein and had a high content of lipids or fat. Proteins present in egg are distributed among the egg white and yolk, whereas lipids are mainly concentrated in the yolk (Abeyrathne et al., 2013). The crude protein content in yolk of Pekin duck eggs observed in this study $(15.76 \%)$ was significantly lower $(\mathrm{P}<0.05)$ in comparison to Cherry Valley duck eggs (17.29\%), and also lower than protein content in yolk of Pekin duck eggs in range $17.33-17.70 \%$ reported by Onbasilar et al. (2011), but within range 15.56$16.21 \%$ reported by Okruszek et al. (2006). The crude fat content in yolk of Pekin duck eggs observed in this study $(35.90 \%)$ was significantly higher $(\mathrm{P}<0.05)$ in comparison to Cherry Valley duck eggs (34.46\%) and also higher than fat content in yolk of Pekin duck eggs in range $28.59-30.86 \%$ reported by Okruszek et al. (2006). According to Pikul (1998), the fat content in the duck egg is 2.5 percent higher than that in the hen egg and for this reason the water content in the duck egg is protein content (Raikos et al., 2006). Protein is an essential component of human diet which is needed for the replacement of tissue and supply of energy (Bashir et al., 2015).

lower than that in the hen egg. The yolk ash percentage of Pekin duck eggs observed in this study $(1.92 \%)$ were lower than ash content in yolk of Pekin duck eggs in range $2.51-2.67 \%$ reported by Onbasilar et al. (2011).

The albumen chemical compositions of Pekin duck and Cherry Valley duck eggs are presented in Table 3. The Cherry Valley duck eggs had significantly higher $(\mathrm{P}<0.05)$ dry matter and crude protein content, while Pekin duck eggs had significantly higher $(\mathrm{P}<0.05)$ carbohydrate content. No significant differences were observed in total ash content between Pekin duck and Cherry Valley duck eggs. The albumen dry matter percentages of Pekin duck eggs observed in this study $(12.11 \%)$ was close to albumen dry matter percentage of Pekin duck eggs in range 12.2$12.7 \%$ reported by Ipek and Sozcu (2017) and $12.3 \%$ reported by Sekiguchi et al. (1979), but lower than range $12.44-13.65 \%$ reported by Onbasilar et al. (2011) and $13.66 \%$ reported by Balkan and Biricik (2008).

Table 3. Comparison of albumen chemical composition of Pekin duck and Cherry Valley duck eggs

\begin{tabular}{|c|c|c|}
\hline \multirow{2}{*}{ Parameter } & \multicolumn{2}{|c|}{ Sample } \\
\cline { 2 - 3 } & Pekin duck & Cherry Valley duck \\
\hline Dry matter, \% & $12.11 \pm 1.26^{\mathrm{a}}$ & $13.21 \pm 0.26^{\mathrm{b}}$ \\
\hline Crude protein, \% & $10.35 \pm 1.12^{\mathrm{a}}$ & $11.54 \pm 0.28^{\mathrm{b}}$ \\
\hline Total ash, \% & $0.68 \pm 0.05^{\mathrm{a}}$ & $0.70 \pm 0.04^{\mathrm{a}}$ \\
\hline Carbohydrate, \% & $1.19 \pm 0.13^{\mathrm{a}}$ & $0.97 \pm 0.19^{\mathrm{b}}$ \\
\hline
\end{tabular}

Values are averages of 60 samples \pm standard deviation

Values in the same row followed by different letters are significantly different $(\mathrm{P}<0.05)$

Water content of yolk is much lower than of albumen because of the important lipid content (Roca et al., 1984). According to Balkan and Biricik (2008), water proportion of Pekin duck eggs is similar to that of other domestic duck forms and mallard. According to Kaewmanee et al. (2009), protein is the major constituent of duck egg albumen solids while the amount of lipid in albumen was negligible. The crude protein content in albumen of Pekin duck eggs observed in this study $(10.35 \%)$ was close to albumen protein content of Pekin duck eggs reported by Okruszek et al. (2006) in range $10.43-10.84 \%$, while Onbasilar et al. (2011) reported higher protein content in range $11.39-12.51 \%$. The albumen ash content of 
Pekin duck and Cherry Valley duck eggs observed in this study $(0.68 \%$ and $0.70 \%$, respectively) were lower than albumen ash content of Pekin duck eggs in range 0.97$1.07 \%$ reported by Onbasilar et al. (2011). The ash content gives a measure of total amount of inorganic compounds like minerals present in a food (Bashir et al., 2015). According to Kaewmanee et al. (2009), duck egg albumen had a lower content of ash than had egg yolk and this is confirmed in this study. This study also revealed that Cherry Valley duck eggs contain significantly more ash in the yolk than Pekin duck eggs what is an indication that Cherry Valley duck eggs contain more minerals. On the contrary, Pekin duck eggs contain significantly higher content of carbohydrate in the yolk and albumen than Cherry Valley duck eggs.

The comparison of egg shell chemical composition of Pekin duck and Cherry Valley duck eggs is presented in Table 4. No significant differences were observed in egg shell dry matter percentage values between
Pekin duck and Cherry Valley duck eggs. The crude protein content in egg shell was recorded to be significantly higher $(\mathrm{P}<0.05)$ at Pekin duck eggs, while total ash content was significantly higher $(\mathrm{P}<0.05)$ at Pekin duck eggs. Most of the egg proteins are present in the egg yolk and albumen, while the egg shell contains the rest of the proteins, $9.46 \%$ and $7.22 \%$ in Pekin duck and Cherry Valley duck egg shell, respectively. According to Al-Awwal and Ali (2015), the average eggshell contains $89.9-91.1 \%$ ash content. The results obtained in this study are slightly out of that range, Pekin duck eggs contain $89.21 \%$ and Cherry Valley duck eggs contain $91.83 \%$ in average total ash in egg shell. Calcium is the major component in an eggshell and there is also a small amount of phosphorus and magnesium and trace amounts of other micro elements (Shwetha et al., 2018). In this study Cherry Valley duck egg shell had significantly $(\mathrm{P}<0.05)$ higher calcium content than Pekin duck egg shell, while no significant differences were observed in phosphorus content.

Table 4. Comparison of egg shell chemical composition of Pekin duck and Cherry Valley duck eggs

\begin{tabular}{|l|c|c|}
\hline \multirow{2}{*}{ Parameter } & \multicolumn{2}{|c|}{ Sample } \\
\cline { 2 - 3 } & Pekin duck & Cherry Valley duck \\
\hline Dry matter, \% & $98.68 \pm 0.42^{\mathrm{a}}$ & $99.05 \pm 0.07^{\mathrm{a}}$ \\
\hline Crude protein, \% & $9.46 \pm 0.76^{\mathrm{a}}$ & $7.22 \pm 0.33^{\mathrm{b}}$ \\
\hline Total ash, \% & $89.21 \pm 0.42^{\mathrm{a}}$ & $91.83 \pm 0.32^{\mathrm{b}}$ \\
\hline Calcium, g/100 g & $33.18 \pm 0.83^{\mathrm{a}}$ & $34.56 \pm 0.49^{\mathrm{b}}$ \\
\hline Phosphorus, g/100 g & $0.17 \pm 0.01^{\mathrm{a}}$ & $0.18 \pm 0.01^{\mathrm{a}}$ \\
\hline
\end{tabular}

Values are averages of 60 samples \pm standard deviation

Values in the same row followed by different letters are significantly different $(\mathrm{P}<0.05)$

\subsection{Egg physicochemical properties}

Physicochemical properties of Pekin duck and Cherry Valley duck eggs are presented in Table 5. One of the most important interior egg quality characteristics is the $\mathrm{pH}$ value of the albumen and yolk, and these correlate with embryo development during the incubation period. An albumen $\mathrm{pH}$ between 8.2 and 8.8 is optimal for embryo development (Walsh, 1993). Brake et al. (1997) reported that optimal yolk $\mathrm{pH}$ was about 6.0. In this study, no significant differences of albumen and yolk $\mathrm{pH}$ were observed. The $\mathrm{pH}$ of the albumen of both duck breed eggs was found to be slightly higher than above optimum range, 8.89 and 8.92 for Cherry Valley duck and Pekin duck eggs, respectively. Ipek and Sozcu (2017) reported similar albumen $\mathrm{pH}$ of Pekin duck eggs 8.8-8.9, but some authors reported higher albumen $\mathrm{pH}$ of Pekin duck eggs: 8.93-9.05 (Okruszek et al., 2006), 8.94-8.99 (Okruszek et al., 2008), 9.00 (Kralik et al., 2015) and 9.02 (Onbasilar et al., 
2007). The lower $\mathrm{pH}$ value of Pekin duck egg albumen was reported in range $8.06-8.70$ by Kokoszynski et al. (2007), 8.10-8.52 by Biesiada-Drzazga et al. (2014) and 8.29-8.35 by Yuan et al. (2013). In this study yolk pH was determined as 6.03 and 6.12 for Cherry Valley duck and Pekin duck eggs, respectively. The higher yolk $\mathrm{pH}$ of Pekin duck eggs was reported by Kralik et al. (2015) 6.16 and in range $6.25-6.31$ by Okruszek et al. (2008) and 6.32-6.93 by Okruszek et al. (2006). The lower yolk $\mathrm{pH}$ of Pekin duck egg albumen was reported in range $5.40-5.75$ by BiesiadaDrzazga et al. (2014), 5.87-6.00 by Onbasilar et al. (2007) and 5.9-6.0 by Ipek and Sozcu (2017).

Table 5. Comparison of physicochemical properties of Pekin duck and Cherry Valley duck eggs

\begin{tabular}{|l|c|c|}
\hline \multirow{2}{*}{ Parameter } & \multicolumn{2}{|c|}{ Sample } \\
\cline { 2 - 3 } & Pekin duck & Cherry Valley duck \\
\hline Albumen $\mathrm{pH}$ & $8.92 \pm 0.04^{\mathrm{a}}$ & $8.89 \pm 0.04^{\mathrm{a}}$ \\
\hline Yolk pH & $6.12 \pm 0.08^{\mathrm{a}}$ & $6.03 \pm 0.07^{\mathrm{a}}$ \\
\hline Yolk color L & $69.72 \pm 0.94^{\mathrm{a}}$ & $70.90 \pm 1.96^{\mathrm{a}}$ \\
\hline Yolk color a & $19.02 \pm 1.83^{\mathrm{a}}$ & $15.60 \pm 2.15^{\mathrm{b}}$ \\
\hline Yolk color b & $69.86 \pm 0.89^{\mathrm{a}}$ & $71.18 \pm 2.56^{\mathrm{a}}$ \\
\hline RYCF scale & $10.79 \pm 0.80^{\mathrm{a}}$ & $9.07 \pm 1.10^{\mathrm{b}}$ \\
\hline
\end{tabular}

Values are averages of 60 samples \pm standard deviation

Values in the same row followed by different letters are significantly different $(\mathrm{P}<0.05)$

The color of the egg yolk is an important quality feature of the egg yolk, being attributed to the high quality of eggs and the products made of eggs (Dvorak et al., 2010). Color of egg yolk is also an important factor in consumer's acceptance of a product. Desirable egg yolk color varies between markets, but yellow to golden colors are usually considered as an indication of better egg quality (Kljak et $a l ., 2012)$. The measurement of egg yolk color according to CIE (1986) $\mathrm{L}^{*} \mathrm{a}^{*} \mathrm{~b}^{*}$ color system showed that no significant differences were observed in this study for the yolk lightness L* value between Pekin duck eggs and Cherry Valley duck eggs $(69.72$ and 70.90, respectively) and also for the yolk yellowness $\mathrm{b}^{*}$ value (69.86 and 71.18 , respectively). The Pekin duck egg yolks were characterized by a significantly higher $(\mathrm{P}<0.05)$ redness $\mathrm{a}^{*}$ value (19.02) than Cherry Valley duck egg yolks (15.60). The similarly $\mathrm{L}^{*}$ values for the Pekin duck egg yolk lightness were reported in range 68.59-70.48 by Okruszek et al. (2006) and in range 70.1-71.0 by Okruszek et al. (2008). The same authors reported considerably lower redness $a^{*}$ value and yellowness $b^{*}$ value for the Pekin duck egg yolks than values observed in this study. Okruszek et al. (2006) reported redness $\mathrm{a}^{*}$ value in range 1.06-3.24 and yellowness $b^{*}$ value in range 38.44-40.99, while Okruszek et al. (2008) reported these values in ranges 1.89-3.21 and 42.9-45.1, respectively. The comparison with these values showed that Pekin duck egg and Cherry Valley duck egg yolks tested in this study had higher intensity of the red and yellow color.

In this study the egg yolk color was also determined by the Roche Yolk Color Fan (RYCF) scale. RYCF scale is a common tool used to determine yolk color, but these determinations are highly subjective which makes them difficult to compare with determinations made in different conditions (Kljak et al., 2012). Marked differences exist in the preference of egg yolk color hue between the consumers in various European countries. Consumers in Germany, Netherlands, Spain, and Belgium prefer egg yolk color with the values 13-14 of RYCF scale, in France, south England, and Finland with the values 11-12 of 
RYCF scale, and in Ireland, north England, and Sweden with the values of 8-9 RYCF scale (Bovskova et al., 2014). On the other hand, US consumers prefer egg yolk color with the values of 7-10 RYCF scale (Galobart et al., 2004). According to Sencic and Butko (2006), Croatian consumers prefer egg yolks with intensive golden, almost orange color with 10 to 12 value on RYCF scale. In this study, the average RYCF value for Pekin duck egg yolks (10.79) was significantly higher $(\mathrm{P}<0.05)$ than average RYCF value for Cherry Valley duck egg yolks (9.07), which showed that Pekin duck egg yolks had more intensive color. Similar RYCF value for Pekin duck egg yolks 9.56 was reported by Kralik et al. (2015), while much lower RYCF values in range 5.67-6.90 were reported by Biesiada-Drzazga et al. (2014).

\section{Conclusions}

Based on the obtained results in this study, it can be concluded that duck breed had significant influence on egg chemical composition. Statistically significant differences $(\mathrm{P}<0.05)$ between Pekin duck and Cherry Valley duck eggs were observed in egg yolk, albumen and shell chemical composition. The Cherry Valley duck eggs had significantly higher crude protein content in yolk and albumen. The Pekin duck eggs had significantly higher crude fat content in yolk, carbohydrate content in yolk and albumen and total ash content in the egg shell. There were not so many differences in egg physicochemical characteristics between two duck breeds. No significant differences of albumen and yolk $\mathrm{pH}$ were observed, but Pekin duck egg yolks had more intensive color. The results obtained in this study could be useful for food industry when selecting eggs as ingredients for different products.

\section{References}

Abeyrathne, E.D., Lee, H.Y., Ahn, D.U. (2013). Egg white proteins and their potential use in food processing or as nutraceutical and pharmaceutical agents - a review. Poultry Science, 92(12), 32923299.

Al-Awwal, N.Y., Ali, U.L. (2015). Proximate analyses of different samples of egg shells obtained from Sokoto market in Nigeria. International Journal of Science and Research, 4(3), 564-566.

Al-Obaidi, F.A., Al-Shadeedi, S.M.J. (2016). Comparison study of egg morphology, component and chemical composition of Mallard duck and domestic Pekin duck. Journal of Genetic and Environmental Resources Conservation, 4(1), 5-9.

AOAC (1980). Official methods of analysis of the AOAC. $\left(13^{\text {th }}\right.$ ed.). Arlington, VA: The Association of Official Analytical Chemists.

Ayim-Akonor, M., Akonor, P.T. (2014). Egg consumption: patterns, preferences and perceptions among consumers in Accra metropolitan area. International Food Research Journal, 21(4), 1457-1463.

Balkan, M., Biricik, M. (2008). Main egg characteristics in the Peking duck (Anas platyrhynchos f. dom.). DU Ziya Gokalp Egitim Fakultesi Dergisi, 11, 142-150.

Bashir, L., Ossai, P.C., Shittu, O.K., Abubakar, A.N., Caleb, T. (2015). Comparison of the nutritional value of egg yolk and egg albumin from domestic chicken, Guinea fowl and hybrid chicken. American Journal of Experimental Agriculture, 6(5), 310-316.

Biesiada-Drzazga, B., Charuta, A., Banaszewska, D. (2014). Evaluation of particular traits of Pekin duck breed star 53 of French origin eggs during egg laying. Veterinarija ir Zootechnika, 67(89), 3-9.

Bovskova, H., Mikova, K., Panovska, Z. (2014). Evaluation of egg yolk colour. Czech Journal of Food Science, 32(3), 213217.

Brake, J., Walsh, T.J., Benton, C.E., Petite, J.N., Meijerhof, R., Penalva, G. (1997). Egg handling and storage. Poultry Science, 76(1), 144-151.

CIE (1986). Colorimetry. (2 ${ }^{\text {nd }}$ ed.). Vienna: Commission Internationale de l'Eclaraige. 
Dvorak, P., Suchy, P., Strakova, E., Dolezalova, J. (2010). Variation in egg yolk colour in different systems of rearing laying hens. Acta Veterinaria Brno, 79(Suppl. 9), 13-19.

El-Soukkary, F.A.H., Mohamed, H.M.A., Dawoodand, A.A.A., Abd-El Sayed, S.Y. (2005). Physico-chemical, microbiological and lipid characteristics of duck meat. Minufiya Journal of Agricultural Research, 30(2), 527-548.

Etuk, I.F., Ojewola, G.S., Abasiekong, S.F., Amaefule, K.U., Etuk, E.B. (2012). Egg quality of Muscovy ducks reared under different management systems in the humid tropics. Revista Cientifica UDO Agricola, 12(1), 225-228.

Galobart, J., Sala, R., Rincon-Carruyo, X., Manzanilla, E.G., Vila, B., Gasa, J. (2004). Egg yolk color as affected by saponification of different natural pigmenting sources. Journal of Applied Poultry Research, 13(2), 328-334.

Huang, J.F., Lin, C.C. (2011). Production, composition and quality of duck eggs. In Y. Nys, M. Bain, F. Van Immerseel (Ed.), Improving the safety and quality of eggs and egg products. (pp. 487-508), Sawston: Woodhead Publishing.

Huang, J.F., Pingel, H., Guy, G., Lukaszewicz, E., Baeza, E., Wang, S.D. (2012). A century of progress in waterfowl production, and a history of the WPSA Waterfowl Working Group. World's Poultry Science Journal, 68(3), 551-563.

Ipek, A., Sozcu, A. (2017). Comparison of hatching egg characteristics, embryo development, yolk absorption, hatch window and hatchability of Pekin Duck eggs of different weights. Poultry Science, 96(10), 3593-3599.

Kaewmanee, T., Benjakul, S., Visessanguan, W. (2009). Changes in chemical composition, physical properties and microstructure of duck egg as influenced by salting. Food Chemistry, 112(3), 560-569.

Kljak, K., Drdic, M., Karolyi, D., Grbesa, D. (2012). Pigmentation efficiency of Croatian corn hybrids in egg production. Croatian Journal of Food Technology, Biotechnology and Nutrition, 7(Special Issue), 23-27.

Kokoszynski, D., Bernacki, Z., Korytkowska, H. (2007). Eggshell and egg content traits in Peking duck eggs from the P44 reserve flock raised in Poland. Journal of Central European Agriculture, 8(1), 9-16.

Kralik, Z., Grcevic, M., Radisic, Z., Mahmutovic, H. (2015). The quality of eggs of different duck breeds. In M. Pospisil (Ed.), Proceedings of $50^{\text {th }}$ Croatian and $10^{\text {th }}$ International Symposium on Agriculture. (pp. 443-446), Opatija: University of Zagreb Faculty of Agriculture.

Lopez-Fandino, R., Recio, I., Ramos, M. (2007). Egg-protein-derived peptides with antihypertensive activity. In R. Huopalahti, R. Lopez-Fandino, M. Anton, R. Schade (Ed.), Bioactive egg compounds. (pp. 199211), Berlin: Springer.

Miranda, J.M., Anton, X., Redondo-Valbuena, C., Roca-Saavedra, P., Rodriguez, J.A., Lamas, A., Franco, C.M., Cepeda, A. (2015). Egg and egg-derived foods: Effects on human health and use as functional foods. Nutrients, 7(1), 706-729.

Okruszek, A., Ksiazkiewicz, J., Woloszyn, J., Kisiel, T., Orkusz, A., Biernat, J. (2006). Effect of laying period and duck origin on egg characteristics. Archiv für Tierzucht, 49(4), 400-410.

Okruszek, A., Ksiazkiewicz, J., Woloszyn, J., Biernat, J., Haraf, G., Orkusz A. (2008). Selected egg quality traits of Pekin type ducks from conservative flocks. Archiv für Geflügelkunde, 72(6), 269- 274.

Onbasilar, E.E., Poyraz, O., Erdem, E. (2007). Effects of egg storage period on hatching egg quality, hatchability, chick quality and relative growth in Pekin ducks. Archiv für Geflügelkunde, 71(4), 187- 191.

Onbasilar, E.E., Erdem, E., Poyraz, O., Yalcin, S. (2011). Effects of hen production cycle and egg weight on egg quality and composition, hatchability, duckling quality, 
and first-week body weight in Pekin ducks. Poultry Science, 90(11), 2642-2647.

Owen, M., Jorgensen, F., Willis, C., McLauchlin, J., Elviss, N., Aird, H., Fox, A., Kaye, M., Lane, C., de Pinna, E. (2016). The occurrence of Salmonella spp. in duck eggs on sale at retail or from catering in England. Letters in Applied Microbiology, 63(5), 335-339.

Pikul, J. (1998). Characteristics of duck eggs and the quality of duck eggs products. Archiv für Geflügelkunde, 62(2), 72-82.

Powrie, W.D., Nakai, S. (1986). The chemistry of eggs and egg products. In W.J. Stadelman, O.J. Cotterill (Ed.), Egg science and technology. (pp. 97-139), Westport, CT: The Avi Publishing Company Inc..

Raikos, V., Hansen, R., Campbell, L., Euston, S.R. (2006). Separation and identification of hen egg protein isoforms using SDSPAGE and 2D gel electrophoresis with MALDI-TOF mass spectrometry. Food Chemistry, 99(4), 702-710.

Roca, P., Sainz, F., Gonzalez, M., Alemany, M. (1984). Structure and composition of the eggs from several avian species. Comparative Biochemistry and Physiology Part A: Physiology, 77(2), 307-310.

SAS Institute (2004). SAS/STAT User's Guide for Personal Computer. Cary, NC: SAS Institute Inc..

Sekiguchi, M., Matsuoka, H., Sasago, K. (1979). Comparison of compositions of duck eggs and their yolk electrophoretic patterns. Journal of Japanese Society of Nutrition and Food Science, 32(2), 93-97.

Sencic, D., Butko, D. (2006). Productivity of layers and egg yolk quality in free range and cage system of housing. Agriculture, 12(2), 48-51.

Shwetha, A., Dhananjaya, Shravana Kumara, S.M., Ananda (2018). Comparative study on calcium content in egg shells of different birds. International Journal of Zoology Studies, 3(4), 31-33.

Walsh, T. J. (1993). The effects of flock age, storage humidity, carbon dioxide, and length of storage on albumen characteristics, weight loss and embryonic development of broiler eggs. MSc thesis. Raleigh, NC: North Carolina State University.

Yuan, J., Wang, B., Huang, Z., Fan, Y., Huang, C., Hou, Z. (2013). Comparison of egg quality traits, egg weight loss and hatchability between striped and normal duck eggs. British Poultry Science, 54(2), 265-269. 